\title{
The Effects of Elephant Grass Silage Combined with Indigofera sp. on the Performance of Bali Cattle
}

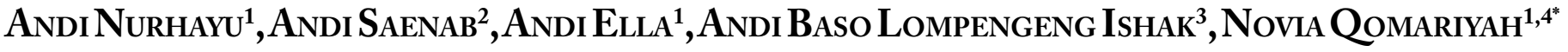 \\ ${ }^{1}$ South Sulawesi Assessment Institute for Agricultural Technology (South Sulawesi ALAT), Makassar 90243, \\ Indonesia; ${ }^{2}$ Center for research and development of animal husbandry Bogor Indonesia (16128); ${ }^{3}$ Indonesian \\ Research Institute for Animal Production, Ciawi Bogor 16720, Indonesia; ${ }^{4}$ Animal Feed and Nutrition Modelling \\ (AFENUE) Research Group, Faculty of Animal Science, IPB University, Bogor 16680, Indonesia.
}

\begin{abstract}
The study aimed to determine the effect of elephant grass silage combined with different levels of Indigofera sp. on body weight gain, intake and feed conversion ratio. Twenty-five individually caged Bali cattle were used in this study, allocated to five treatment groups consisting of five animals in each group following a randomized complete design. The treatments were T1: elephant grass silage 100\% + Indigofera sp. 0\%; T2: elephant grass silage 70\% + Indigofera sp. 30\%; T3: elephant grass silage 60\% + Indigofera sp. 40\%; T4: elephant grass silage 50\% + Indigofera sp. 50\%; and T5: elephant grass silage $40 \%+$ Indigofera sp. $60 \%$. Variables measured were the quality of silage and the performance of Bali cattle fed various dietary treatments. The results showed that the physical characteristics of silage were similar for all treatments. The silage was brown to greenish in colour, had minimum odour from the formation of lactic acid, had solid texture, and was compact. There was no mould growth in the silage, and $\mathrm{pH}$ ranged from 3.7 to 4.1 . Increasing levels of Indigofera sp. added to elephant grass increased the crude protein content of silage, but decreased the content of ash, acid detergent fibre (ADF), neutral detergent fibre (NDF), cellulose, hemicellulose and lignin by up to $40 \%$. Dry matter intake per kg unit of BW was higher $(\mathrm{P}<0.000)$ in the T2, T3, and T4 diet than in the T1 or T5 diets. The crude protein intake per $\mathrm{kg}$ unit of $\mathrm{BW}$ was higher $(\mathrm{P}<0.000)$ in the $\mathrm{T} 3, \mathrm{~T} 4, \mathrm{~T} 5$ diet than $\mathrm{T} 1$ and $\mathrm{T} 2$. Animals on the T3 diet showed a higher $(\mathrm{P}<0.05)$ daily $\mathrm{BW}$ gain followed by the animals on the T4 and T5 diets. It can be concluded that the combination of $60 \%$ elephant grass and $40 \%$ Indigofera sp. has the best physical and chemical qualities and is able to increase the daily body weight of Bali cattle.
\end{abstract}

Keywords | Silage, Elephant grass, Indigofera sp, Bali cattle, Performance

Received | February 18, 2021; Accepted | March 14, 2021; Published | July 01, 2021

*Correspondence | Novia Qomariyah, South Sulawesi Assessment Institute for Agricultural Technology (South Sulawesi AIAT), Makassar 90243, Indonesia; Email: noviabptpsulsel@gmail.com

Citation | Nurhayu A, Saenab A, Ella A, Ishak ABL, Qomariyah N (2021). The effects of elephant grass silage combined with indigofera sp. On the performance of bali cattle. J. Anim. Health Prod. 9(3): 229-235.

DOI | http://dx.doi.org/10.17582/journal.jahp/2021/9.3.229.235

ISSN | 2308-2801

Copyright (C) 2021 Qomariyah et al. This is an open access article distributed under the Creative Commons Attribution License, which permits unrestricted use, distribution, and reproduction in any medium, provided the original work is properly cited.

\section{INTRODUCTION}

$\mathrm{F}$ orages are important for the efficient operation of systems for the processing of livestock. During the dry season, both the quantity and quality of this forage are poor and constitute major restrictions on the production of ruminant livestock. Dynes et al. (2003) state that forage, whether fed as pasture, forage crops, or preserved grass, si- lage, or haylage, is the most important component in cattle diets. Meanwhile, climate change has the potential to affect the quantity and reliability of output of forage and its quality (Rojas-Downing et al., 2017). Legumes, a high protein source of forage, are used to substitute for grass in cattle diets to fulfil the protein requirements of livestock. Moreover, legumes are one of the alternatives used in intensification systems for ruminant production in pasture, 
for improvement and diversification of feed, and for reduction of production costs (Sales et al., 2012). Legumes can reduce the greenhouse gas emissions of ruminant production (Lüscher et al., 2014), because they contain saponin (6-15\%), tannins (up to 10\%), polyphenol oxidase, and protease (Mueller-Harvey, 2006; Kingston-Smith et al., 2010). Indigofera sp. is a leguminous tree that has potential as a source of dietary protein and energy, and which has high levels of dry matter and organic matter digestibility (Tarigan et al., 2010).

Several experiments have shown that feeding animals with legume silage increases milk production compared to animals fed only on grass silage (Dewhurst et al., 2003). Rumen nitrogen $(\mathrm{N})$ loss in ruminants fed legumes as their sole diet was higher due to an imbalance in availability between the degradable $\mathrm{N}$ present and the fermentable energy supplied by this forage. The breakdown of rumen protein was higher in forage legumes compared to grass (Beever et al., 1986) because of inefficient utilization of $\mathrm{N}$ in the rumen and high urinary $\mathrm{N}$ excretion (Peyraud, 1993). The water soluble carbohydrates (WSC) contained in the forage must be sufficient to balance crude protein concentration in order to maximize microbial protein synthesis. Legumes usually contain high levels of crude protein and low WSC concentrations; therefore, increasing WSC concentration can improve $\mathrm{N}$-rumen utilization and feed digestibility. Combining grass containing high WSC concentrations with legumes containing high crude protein content is expected to improve digestibility. This study aims to determine the quality of elephant grass silage combined with various levels of Indigofera sp. and its effects on the performance of Bali cattle.

\section{MATERIALS AND METHODS}

\section{Experimental Animals}

This study used 25 Bali cattle aged from 2.5 to 5 years and with bodyweight of 160-170 kg. The research was conducted in Gowa Experimental Field Station, South Sulawesi. The experiment was approved by the Animal Welfare Commission of the Indonesian Agency for Agricultural Research and Development (Balitbangtan/BPTP Sulsel/Rm/03/2020). Cattle were raised using the animal welfare standards of the Indonesian Centre of Agriculture Research and Development, Ministry of Agriculture.

\section{TrEatMENT GROUPS AND ANALYSES}

Elephant grass and Indigofera sp. used in the experiment were cut at 60 days regrowth and obtained from Gowa Experimental Field Station. The ensilage was conducted by mixing fresh elephant grass and Indigofera sp. with starters consisted of rice bran and molasses as much as $5 \%$ of the total weight of forage. Elephant grass, Indigofera sp. and rice bran were mixed thoroughly, put into $60 \times 100 \mathrm{~cm}$ plastic bags to create anaerobic conditions, and then kept for 21 days. The silage was prepared according to the following treatments: T1 (100\% elephant grass + Indigofera sp. 0\%), T2 (elephant grass 70\% + Indigofera sp. 30\%), T3 (elephant grass $60 \%+$ Indigofera sp. 40\%), T4 (elephant grass 50\% + Indigofera sp. 50\%), and T5 (elephant grass $40 \%+$ Indigofera sp. 60\%). Each treatment was carried out in five replications. The ensiling procedure was performed according to Kondo et al. (2014). The silage was harvested after 21 days to determine physical characteristics of colour, smell, texture, mould presence, and $\mathrm{pH}$. Silage samples were oven-dried at $60^{\circ} \mathrm{C}$ for 24 hours then ground with a screen size of $1 \mathrm{~mm}$. Samples were analysed in duplicate for their chemical composition of dry matter (DM), organic matter $(\mathrm{OM})$, ash, crude protein $(\mathrm{CP})$, ether extract (EE), crude fibre (CF), and nitrogen-free extract (NFE) by following the AOAC procedure (2005). Samples were also analysed for NDF, acid detergent fibre (ADF), and lignin (Van Soest et al., 1991).

\section{IN VIVO EXPERIMENT}

Cattle were raised in individual cages and fed twice a day, first at 07.00 with silage and concentrate, and then at 16.00 with silage alone. The concentrate contained $15 \%$ crude protein and consisted of $50 \%$ rice bran, $15.5 \%$ coconut cake, $19 \%$ milled corn, $15 \%$ fish meal, $0.25 \%$ minerals, and $0.25 \%$ salt. The concentrate was given at $2 \mathrm{~kg} /$ head/day, while drinking water was given ad libitum. The feed treatments were carried out for four months, and feed intake was determined by weighing the feed offered and feed remaining every day during the four-month period. The animals were weighed once a month to evaluate body weight gain.

\section{STATISTICAL ANALYSIS}

Data were analysed using analysis of variance (ANOVA) for the five treatments and five replications. When the ANOVA results for a certain parameter showed a significant difference at $p<0.05$, the Duncan test was applied to compare the differences among the treatments. Statistical analysis was performed by using SPSS statistics software version 23.

The ANOVA model is:

$\mathrm{Yij}=\mu+\alpha \mathrm{ij}+\varepsilon \mathrm{i}$

where:

Yij = observed variable response

$\mu=$ general average

$\alpha \mathrm{ij}=$ the effect of the $\mathrm{i}$-th feed on the $\mathrm{j}$-th test

Eij $=$ effect of the error component

$\mathrm{i}=1,2,3,4$

$\mathrm{j}=1,2,3,4$ 
Table 1: Physical characteristics of elephant grass silage combined with various levels of Indigofera sp.

$\begin{array}{llllll}\text { Treatment* } & \text { Colour } & \text { Odour } & \text { Texture } & \text { Fungi } & \text { pH } \\ \text { T1 } & \text { the brownish-green, } & \text { Typical lactic acid } & \text { Whole and compact } & \text { No fungi } & 4.3 \\ \text { T2 } & \text { the brownish-green, } & \text { Typical lactic acid } & \text { Whole and compact } & \text { No fungi } & 4.3 \\ \text { T3 } & \text { the brownish-green, } & \text { Typical lactic acid } & \text { Whole and compact } & \text { No fungi } & 4 \\ \text { T4 } & \text { the brownish-green, } & \text { Typical lactic acid } & \text { Whole and compact } & \text { No fungi } & 4.5 \\ \text { T5 } & \text { the brownish-green, } & \text { Typical lactic acid } & \text { Whole and compact } & \text { No fungi } & 4.5\end{array}$

*T1 (100\% elephant grass + Indigofera sp. 0\%); T2 (elephant grass 70\% + Indigofera sp. 30\%); T3 (elephant grass 60\% + Indigofera sp. 40\%); T4 (elephant grass 50\% + Indigofera sp. 50\%); T5 (elephant grass 40\% + Indigofera sp. 60\%)

Table 2: Chemical composition of elephant grass silage combined with various levels of Indigofera sp.

\begin{tabular}{lllllllll} 
Treatments* & \multicolumn{2}{l}{ Composition (\%) } & & & & \\
& DM & CP & Ash & ADF & NDF & Cellulose & Hemicellulose & Lignin \\
T1 & 92.98 & 7.81 & 14.39 & 47.89 & 68.86 & 34.77 & 21.28 & 9.81 \\
T2 & 91.42 & 12.26 & 17.12 & 47.64 & 64.21 & 27.74 & 16.36 & 13.29 \\
T3 & 91.12 & 18.81 & 14.66 & 47.33 & 55.60 & 26.69 & 8.28 & 14.07 \\
T4 & 88.70 & 16.74 & 14.62 & 48.50 & 61.57 & 29.65 & 13.08 & 16.77 \\
T5 & 88.15 & 15.48 & 15.46 & 48.79 & 60.48 & 34.94 & 13.14 & 16.64
\end{tabular}

DM: Dry Matter, CP: Crude Protein, ADF: Acid Detergent Fiber, NDF: Neutral Detergent Fiber.

*T1 (100\% elephant grass + Indigofera sp. 0\%); T2 (elephant grass 70\% + Indigofera sp. 30\%); T3 (elephant grass 60\% + Indigofera sp. 40\%); T4 (elephant grass 50\% + Indigofera sp. 50\%); T5 (elephant grass 40\% + Indigofera sp. 60\%)

Table 3: Effects of Elephant grass silage combined with Indigofera sp. on total intake, total organic intake and crude protein intake.

\begin{tabular}{llllllll} 
Parameters & \multicolumn{2}{l}{ Treatment* $^{*}$} & & & & SEM & P-value \\
& T1 & T2 & T3 & T4 & T5 & & \\
Total dry matter intake $(\mathrm{kg} / \mathrm{d})$ & $6.18^{\mathrm{ab}}$ & $6.16^{\mathrm{ab}}$ & $6.43^{\mathrm{c}}$ & $6.26^{\mathrm{b}}$ & $6.04^{\mathrm{a}}$ & 0.053 & 0.001 \\
Total organic matter intake $(\mathrm{kg} / \mathrm{d})$ & $5.30^{\mathrm{b}}$ & $5.35^{\mathrm{b}}$ & $5.48^{\mathrm{c}}$ & $5.31^{\mathrm{b}}$ & $4.96^{\mathrm{a}}$ & 0.022 & 0.000 \\
Crude protein intake $(\mathrm{kg} / \mathrm{d})$ & $0.51^{\mathrm{a}}$ & $0.75^{\mathrm{b}}$ & $1.28^{\mathrm{d}}$ & $1.17^{\mathrm{d}}$ & $1.06^{\mathrm{c}}$ & 0.037 & 0.000
\end{tabular}

abc: means in the same line with varying superscript differ significantly $(\mathrm{P}<0.05)$.

*T1 (100\% elephant grass + Indigofera sp. 0\%); T2 (elephant grass 70\% + Indigofera sp. 30\%); T3 (elephant grass 60\% + Indigofera sp. 40\%); T4 (elephant grass 50\% + Indigofera sp. 50\%); T5 (elephant grass 40\% + Indigofera sp. 60\%)

\section{RESULTS}

In general, the quality of silage produced was acceptable in terms of physical characteristics (Table 1) and chemical components (Table 2). The physical characteristics of silage show that all silage treatments had the same brown to greenish colour, had a distinctive odour of lactic acid, a whole and compact texture, and no mould growth, with the only difference between each treatment being $\mathrm{pH}$ value. The highest dry matter content was in T1, at 92.98\%, while the lowest dry matter content was in T5, at $81.15 \%$. T3 contained higher crude protein compared to the other silage treatments. The ash content in T2 compared to the other silage treatments. The T2 and T1 treatments had more ash content than T3 at $47.89 \%$ and $47.64 \%$, respectively. The lowest $\mathrm{ADF}$ content was in $\mathrm{T} 3$, at $47.33 \%$. The $\mathrm{T} 4$ and $\mathrm{T} 5$ treatments had the highest $\mathrm{ADF}$ content, at $48.50 \%$ and $48.79 \%$, respectively. The lowest cellulose content was in $\mathrm{T} 3$, at $27.74 \%$, and the highest was in T5 at $34.94 \%$.
Effects of Elephant grass silage combined with Indigofera sp. on total intake, total organic intake and crude protein intake were presented in Table 3. The total DM intake of the cattle fed with the T3 (elephant grass $60 \%+$ Indigofera sp. 40\%) diet was higher $(\mathrm{p}<0.001)$ compared to those fed with T5 (elephant grass 40\% + Indigofera sp. 60\%) (Table 3). The total OM intake of the cattle feed with the $\mathrm{T} 5$ (elephant grass $40 \%+$ Indigofera sp. 60\%) diet was lower $(\mathrm{p}<0.000)$ compared to those fed with T3 (elephant grass $60 \%+$ Indigofera sp. $40 \%)$ diet. The total CP intake of the cattle fed with T3 (elephant grass 60\% + Indigofera sp. 40\%) diet was higher $(\mathrm{p}<0.000)$ compared to those fed with the T1 (elephant grass $100 \%+$ Indigofera sp. $0 \%$ ) diets. Effects of Elephant grass silage combined with Indigofera sp. on digestibility nutrient and nitrogen retention were presented in Table 4 . The dry matter and crude protein digestibility of cattle in treatment T3 was significantly higher $(\mathrm{p}<0.000)$ compared to treatment T1. The organic 
Table 4: Effects of Elephant grass silage combined with Indigofera sp. on nutrient digestibility and nitrogen retention.

\begin{tabular}{llllllll} 
Parameters & Treatment & & & & & SEM & P -value \\
& T1 & T2 & T3 & T4 & T5 & & \\
Dry matter (\%) & $41.43^{\mathrm{a}}$ & $44.50^{\mathrm{ab}}$ & $48.50^{\mathrm{c}}$ & $46.57^{\mathrm{bc}}$ & $44.17^{\mathrm{ab}}$ & 1.011 & 0.000 \\
\hline Organic matter (\%) & $21.14^{\mathrm{b}}$ & $23.61^{\mathrm{b}}$ & $28.73^{\mathrm{c}}$ & $20.47^{\mathrm{b}}$ & $12.31^{\mathrm{a}}$ & 1.485 & 0.000 \\
\hline Crude protein (\%) & $44.13^{\mathrm{a}}$ & $62.47^{\mathrm{b}}$ & $81.20^{\mathrm{c}}$ & $78.25^{\mathrm{c}}$ & $74.82^{\mathrm{c}}$ & 2.174 & 0.000 \\
\hline Nitrogen in feces (g/head/day) & $46.48^{\mathrm{d}}$ & $43.62^{\mathrm{c}}$ & $38.10^{\mathrm{a}}$ & $40.98^{\mathrm{b}}$ & $42.77^{\mathrm{bc}}$ & 0.803 & 0.000 \\
\hline Nitrogen in urine $(\mathrm{g} / \mathrm{head} /$ day) & $10.18^{\mathrm{a}}$ & $12.26^{\mathrm{c}}$ & $12.62^{\mathrm{d}}$ & $11.27^{\mathrm{b}}$ & $10.41^{\mathrm{a}}$ & 0.105 & 0.000 \\
\hline Nitrogen digested $(\mathrm{g} / \mathrm{head} /$ day) & $77.38^{\mathrm{a}}$ & $120.86^{\mathrm{b}}$ & $149.77^{\mathrm{c}}$ & $168.21^{\mathrm{d}}$ & $193.33^{\mathrm{e}}$ & 1.245 & 0.000 \\
\hline Nitrogen retention(g/head/day) & $39.92^{\mathrm{a}}$ & $63.90^{\mathrm{b}}$ & $71.44^{\mathrm{c}}$ & $75.62^{\mathrm{d}}$ & $80.28^{\mathrm{e}}$ & 0.514 & 0.0000
\end{tabular}

abcd: means in the same line with varying superscript differ significantly ( $<<0.05) ;{ }^{*} \mathrm{~T} 1$ (100\% elephant grass + Indigofera sp. 0\%); T2 (elephant grass 70\% + Indigofera sp. 30\%); T3 (elephant grass 60\% + Indigofera sp. 40\%); T4 (elephant grass 50\% + Indigofera sp. 50\%); T5 (elephant grass 40\% + Indigofera sp. 60\%)

Table 5: Effects of feeding of Elephant grass silage combined with Indigofera sp. on growth performance of Bali cattle.

\begin{tabular}{|lllllllll} 
Parameters & Treatment* & & & & & SEM & P -value \\
& T1 & T2 & T3 & T4 & T5 & & \\
Initial body weight $(\mathrm{kg})$ & 170.1 & 169.4 & 170.8 & 169.8 & 161 & 5.758 & 0,737 \\
\hline Final body weight $(\mathrm{kg})$ & 191.6 & 195.4 & 204.2 & 200.6 & 189.6 & 4.248 & 0.130 \\
Average daily gain $(\mathrm{kg} / \mathrm{h} / \mathrm{d})$ & $0.24^{\mathrm{a}}$ & $0.29^{\mathrm{ab}}$ & $0.37^{\mathrm{b}}$ & $0.34^{\mathrm{b}}$ & $0.31^{\mathrm{ab}}$ & 0.029 & 0.045 \\
\hline Feed conversion ratio & $27.20^{\mathrm{b}}$ & $20.18^{\mathrm{a}}$ & $19.24^{\mathrm{a}}$ & $19.87^{\mathrm{a}}$ & $22.97^{\mathrm{a}}$ & 1.246 & 0.001
\end{tabular}

abc: means in the same line with varying superscript differ significantly $(\mathrm{P}<0.05) ;{ }^{*} \mathrm{~T} 1$ (100\% elephant grass + Indigofera sp. 0\%); T2 (elephant grass 70\% + Indigofera sp. 30\%); T3 (elephant grass 60\% + Indigofera sp. 40\%); T4 (elephant grass 50\% + Indigofera sp. 50\%); T5 (elephant grass 40\% + Indigofera sp. 60\%)

matter digestibility of cattle in treatment T3 was significantly higher $(\mathrm{p}<0.000)$ compared to treatment T5. The $\mathrm{N}$ feces was highest $(\mathrm{p}<0.000)$ in cattle fed $100 \%$ elephant grass in treatment $\mathrm{T} 1$, but the $\mathrm{N}$ urine was lowest $(\mathrm{p}<0.000)$ in cattle fed treatment T1 compared to other groups. The nitrogen digested and $\mathrm{N}$ retention was highest $(\mathrm{p}<0.000)$ in cattle fed T5, but was lowest $(\mathrm{p}<0.000)$ in cattle fed T1.

Effects of Elephant grass silage combined with Indigofera sp. on growth performance were presented in Table 5 . There was no difference in the initial and final body weight among the five dietary treatment groups. However, the animals fed with the T3 diet resulted in lower feed conversion ratio $(\mathrm{p}<0.001)$ than $\mathrm{T} 1$ diets (Table 5).

\section{DISCUSSION}

The purpose of silage production is to provide a form of stable feed with dry matter, energy, and other nutrients that are easily digested compared to fresh plants (Kung Jr. et al., 2018). Loss of dry matter and quality that occurs during the ensiling process from the field, to the trial phase, to livestock is unavoidable (Borreani et al., 2018). Based on the characteristics of silage observed, the five silage treatments in the study were suitable for cattle feed, because the $\mathrm{pH}$ values ranged from 3.7 to 4.1 and they were not contaminated with mould. The lowest $\mathrm{pH}$ was 3.7 in $\mathrm{T} 1$, followed by $\mathrm{T} 2$ at 3.9. Meanwhile, the $\mathrm{pH}$ for both $\mathrm{T} 3$ and $\mathrm{T} 4$ was 4 , and the highest $\mathrm{pH}$ was for T5, at 4.1. A good-quality silage has a $\mathrm{pH}$ between 3.8 and 4.2 and a smooth texture, brown-greenish colour, smells of lactic acid, has water content of about $60-70 \%$ and has a good smell (Ratnakumolo et al., 2006).

Our results illustrate that increasing levels of Indigofera sp. addition to elephant grass silage resulted in lower dry matter content. According to McCullough (1977), the potential of elephant grass for silage depends on the concentration of its water content. Loss of dry matter is also influenced by the cutting time and withering of the forage, in which late afternoon cutting can increase WSC (Morin et al., 2012; Brito et al., 2008). In addition, the dry matter content of silage can determine quality, in that the dry matter content of forage can affect the shelf life of silage (Kuncoro et al., 2015). Dry silages can break down quickly when exposed to air because they tend to be more porous in silos than wet silages. These silages do not have sufficient amounts of organic acids (e.g., acetic acid) with antifungal activity to suppress lactate-assimilating yeast growth, a condition which triggers decay in aerobic conditions (Kung Jr et al., 2018).

Protein is one of the most important nutrients and is need- 
ed by livestock at various levels of production and various phases of life. This study shows that the crude protein content of silage increased with increasing levels of added Indigofera sp. This is presumably because Indigofera sp. has high protein content, so mixing it with elephant grass silage will increase the crude protein content of the silage. This is in line with the opinion of Riswandi et al. (2016) that the nutritional quality of grass can be improved by supplementation with legumes. The crude protein content of Indigofera sp. leaves varies from 24.2 to $31 \%$ (Hassen et al., 2007; Muzzazinah, 2016).

Ash content can be used to determine the minerals contained in a material, which in turn can indicate the success of the demineralization process that has occurred (Kuncoro et al., 2015). The ash content in T2 is the highest $17.12 \%$, respectively, followed by $\mathrm{T} 5, \mathrm{~T} 3, \mathrm{~T} 4$ which have $15.46 \%$, $14.66 \%$ and $14.62 \%$ of ash content, respectively. T1 has the lowest ash content at $14.39 \%$. The high ash content in T2 and T3 treatments indicates that the minerals levels contained were higher than the other treatments.

The ADF concentration refers to the cell wall portions of the forage. The ADF value is important because it will influence the ability of animals to digest the forage. As the ADF increases, the digestibility of the forage usually decreases (Salama and Nawar, 2016). In line with the ADF content, the NDF content in the T3 treatment (with the lowest Indigofera sp. level of 40\%) was 55.60\%, however the NDF content of silage increased with increasing Indigofera sp. levels at $50 \%$ and $60 \%$. Meanwhile, elephant grass silage without Indigofera sp. had the highest NDF content, at $68.86 \%$. Albayrak and Turk (2013) state that forage legumes are known to have lower fibre content than grasses, while grasses also generally contain more NDF. This result indicates that addition of Indigofera sp. to elephant grass silage decreased its NDF content. Low NDF values indicates a good-quality silage (Senjaya et al., 2010).

The T3, T2, and T4 treatments had adequate cellulose content, $26.69 \%, 27.74 \%$, and $29.65 \%$, respectively. The hemicellulose content in T3, at $8.28 \%$, was the lowest compared to other silage treatments, while the highest was T1, at $21.28 \%$, followed by $\mathrm{T} 2, \mathrm{~T} 4$, and $\mathrm{T} 5$, at $16.36 \%$, $13.08 \%$, and $13.14 \%$ respectively. The lignin content in T1, at $9.81 \%$. The highest lignin content was in $\mathrm{T} 4$, at $16.77 \%$, then T5, T3 and T2, at 16.64\%, $14.07 \%$ and $13.29 \%$, respectively. These results illustrate that elephant grass silage combined with Indigofera sp. has higher lignin content than silage containing elephant grass alone. Silage with higher Indigofera sp. levels contains greater amounts of lignin than silage with lower Indigofera sp. levels. Lignin is considered as an anti-nutritional component in forage because it has a negative impact on the nutrient availability of plant fi- bre (Moore and Jung, 2001). Lignin also inhibits cell wall digestion to a greater extent than the total dry matter digestibility of forage (Jung and Vogel, 1986). In addition, lignin is closely related to cellulose and hemicellulose and can limit the digestion of polysaccharides (Machado et al., 2020).

The utilization of Indigofera sp. in ruminant feeding has been evaluated (Tarigan et al., 2018; Ginting et al., 2010). The feed intake and digestibility of the nutrients can be enhanced by the use of different techniques for supplementation and processing (Leng, 1990). The present study was carried out to determine whether Elephant grass silage combined with Indigofera sp. can be used efficiently to feed cattle. Dry matter intakes of Elephant grass silage combined with Indigofera sp. were significantly different $(p<0.001)$ among dietary treatments (Table 3$)$. But, numerically higher intake of Elephant grass silage combined with Indigofera sp. and total DM occurred in cattle receiving T3 diets. The high DM, OM and CP intake of T3 diets can be explained by the high CP content (18.81\%) and low content of NDF (55.60\%). These results indicate that Indigofera sp. is good quality protein source in terms of body weight gain. This result is supported by Tarigan et al. (2018) who reported that DM, OM and CP intakes by goat fed on GCP (green concentrate pellets) were greater compared to the control.

The level of crude protein digestibility in the Elephant grass silage combined with Indigofera sp. groups were significantly higher $(\mathrm{p}<0.000)$ compared to the T1 diets. This may relate to the high intake and digestibility of $\mathrm{CP}$ in cattle receiving Indigofera sp. The $\mathrm{N}$ secretion in faeces and urine were significantly lower $(\mathrm{p}<0.000)$ in Elephant grass silage combined with Indigofera sp. groups diets than those of cattle the fed with $0 \%$ Indigofera sp. Increased fecal $\mathrm{N}$ and urine nitrogen could be due to the higher tannin content of Elephant grass silage combined Indigofera sp, which reduced the degradation protein in the rumen. In response to the increasing content of tannin in the feed, a decrease in $\mathrm{N}$ digestibility and increased secretion of urine and feces (A1-Dobaib, 2009). Tannins can slow down protein degradation in the rumen and can also occur in silage, thereby increasing protein utilization and livestock production efficiency (Huang et al., 2018; Jayanegara et al., 2018). N retention in cattle fed treatment $\mathrm{T} 2$ until $\mathrm{T} 5$ has increased by $37.53-50.27 \%$ compared to $\mathrm{T} 1$, indicating the potential of Elephant grass silage combined with Indigofera sp. in supporting the productivity of ruminants.

Silage treatment showed the highest increase in daily body weight gain of Bali cows. These results indicate that elephant grass silage with a combination of Indigofera sp. at levels of $40 \%$ plus concentrate as supplement feed can fulfil 
the nutritional needs of livestock. The feed has high palatability due to good silage quality. However, increasing levels of Indigofera sp. resulted in decreased daily body weight gain in the Bali cows. At the $50 \%$ Indigofera sp. level, body weight gain dropped to $0.34 \mathrm{~kg} / \mathrm{head} /$ day and declined further to $0.31 \mathrm{~kg} / \mathrm{head} /$ day in silage with Indigofera sp. level of $60 \%$. At $30 \%$ Indigofera sp. level body weight gain dropped to 0.29 , this value was almost the same as for silage of elephant grass without Indigofera sp. (0\%), which only increased by $0.24 \mathrm{~kg} / \mathrm{h}$ ead/day of body weight. This might be due to an increase in the content of ADF, NDF, cellulose, hemicellulose, and lignin in the silage treatments. In addition, increasing Indigofera sp. levels cause more tannin content in silage. Indigofera sp. contains anti-nutritional tannins which will become a limiting factor, because most of these substances are toxic (Nurjannah et al., 2019). These tannins can slow down protein degradation in the rumen and can also occur in silage, thereby increasing protein utilization and livestock production efficiency (Huang et al., 2018; Jayanegara et al., 2018). Combination silage at several levels of Indigofera sp. offered to Bali cattle increased feed consumption. The highest levels of consumption were recorded in $\mathrm{T} 2, \mathrm{~T} 3$, and $\mathrm{T} 4$ treatments. This was because the silage had a high level of palatability due to its relatively good quality and nutritional content. Feed that has good palatability will be consumed more readily by livestock (Usman et al., 2013). The palatability of feed is influenced by the smell, taste, texture, and shape of the feed given.

Feed conversion is the amount of feed consumed divided by the bodyweight gain per unit of time. The feed conversion value is more efficient if the amount of feed consumed is less but results in a higher or the same bodyweight gain. Good-quality feed will result in high body weight gain and low feed conversion values. Elephant grass silage combined with several levels of Indigofera sp. had significant effect (P $<0.001$ ) on feed conversion. Treatment T3 had the lowest conversion value of 19.24 , which indicates the treatment was more efficient than the other treatments. Overall, the feed conversion in this study was higher than the feed conversion reported by Tahuk and Dethan (2010), which was 7.55 for fattening Bali cattle fed by local grass and king grass without additional supplements.

\section{CONCLUSION}

Increasing levels of Indigofera sp. in silage up to $40 \%$ resulted in increasing crude protein content, however, the levels of ash, ADF, NDF, cellulose, hemicellulose, and lignin in silage decreased. Silage with a composition of $60 \%$ elephant grass and $40 \%$ Indigofera sp. has the best physical and chemical qualities and is able to increase the daily body weight of Bali cattle compared to other silages.

\section{ACKNOWLEDGEMENT}

This research was supported by Indonesian Agency for Agricultural Research and Development, Ministry of Agricultural, Republic of Indonesia.

\section{CONFLICT OF INTEREST}

All authors declare that there is no conflict of interest.

\section{AUTHORS CONTRIBUTION}

AN carried out the experiment, performed the statistical analysis and wrote the initial manuscript draft. AS, AE, ABLI and NQ designed and supervised the experiment and revised the manuscript.

\section{REFERENCES}

-Al-Dobaib SN (2009). Effect of different levels of quebracho tannin on nitrogen utilization and growth performance of Najdi sheep fed alfalfa (Medicago sativa) hay as a sole diet. Anim. Sci. J. 80(50): 532-541. https://doi.org/10.1111/ j.1740-0929.2009.00662.x.

-Association of Official Analytical Chemists (2005). Official Methods of Analysis, AOAC International, Washington DC, USA.

-Albayrak S, Turk M (2013). Changes in the forage yield and quality of legume-grass mixtures throughout a vegetation period. Turk. J. Agric. For. 37(2): 139-147. https:// doi.org/ 10.3906/tar-1202-73.

- Beever DE, Dhanoa MS, Losada HR, Evans RT, Cammell SB, France J (1986). The effect of forage species and stage of harvest on the process of digestion occurring in the rumen of cattle. Br.J. Nutr. 56: 439-454. https:// doi.org/ 10.1079/ bjn19860124.

-Borreani G, Tabacco E, Schmidt RJ, Holmes BJ, Muck RE (2018). Silase review : Factors affecting dry matter and quality losses in silages. J. Dairy Sci. 101:3952-3979. https:// doi.org/10.3168/jds.2017-13837

- Brito AF, Tremblay GF, Bertrand A, Castonguay Y, Bélanger G, Michaud R, Lapierre H, Benchaar C, Petit HV, Ouellet DR, Berthiaume R (2008). Alfalfa cut at sundown and harvested as baleage improves milk yield of late-lactation dairy cows J. Dairy Sci. 91(10):3968-3982. https://doi.org/10.3168/ jds.2008-1282.

-Dewhurst RJ, Fisher WJ, Tweed JKS, Wilkins RJ (2003). Comparison of grass and legume silages for milk production. 1. Production responses with different levels of concentrate. J. Dairy Sci. 86: 2598- 2611. https://doi. org/10.3168/jds.S0022-0302(03)73855-7

-Dynes RA, Henry DA, Masters DG (2003). Characterising forages for ruminant feeding. Asian-Australasian J. Anim. Sci. 16(1):116-123. https://doi.org/10.5713/ajas.2003.116

- Ginting SP, Rantan K, Juniar S, Antonius (2010). The Utilization of Indigofera sp. as the sole foliage in goat diets supplemented with high carbohydrate or high protein concentrates. JITV 15(4): 261-268. https://doi.org/10.14334/jitv.v15i4.665

- Hassen A, Rethman NFG, van Niekerk WA, Tjelele TJ 
(2007). Influence of season/year and species on chemical composition and in vitro digestibility of five Indigofera accessions. Anim. Feed Sci. Technol. 136: 312-322. http:// dx.doi.org/10.1016/j.anifeedsci.2006.09.010.

-Huang Q, Liu X, Zhao G,Hu T, Wang Y (2018). Potential and challenges of tannins as an alternative to in-feed antibiotics for farm animal production. Anim Nutr. 4(2): 137-150. https://doi.org/10.1016/j.aninu.2017.09.004.

- Jayanegara A, Sujarnoko TUP, Ridla M, Kondo M, Kreuzer M (2019). Silage quality as influenced by concentration and type of tannins present in the material ensiled: A metaanalysis. J. Anim. Physiol. Anim. Nutr. (Berl). 103(2):456465. https://doi.org/10.1111/jpn.13050.

-Jung HG, Vogel KP (1986). Influence of lignin on digestibility of forage cell wall material. J. Anim. Sci. 62(6): 1703-1712. https://doi.org/10.2527/jas1986.6261703x.

- Kingston-Smith AH, Edwards JE, Huws SA, Kim EJ, Abberton M (2010). Plant-based strategies towards minimizing 'livestock's long shadow'. Proceed. Nutrit. Society. 69(4):613- 620. https://doi.org/10.1017/ S0029665110001953.

- Kondo M, Hirano Y, Kita K, Jayanegara A, Yokota H (2014). Fermention characteristics, tannin ensiled and in vitro ruminal defradation of green tea and black tea by-products ensiled at different temperatures. Asian Australas. J. Anim. Sci. 27:(7):937-945. https://doi.org/10.5713/ ajas.2013.13387.

-Kuncoro DC, Muhtarudin, Fathul F (2015). The effect of starter addition in feed silage from agriculture waste to crude protein, dry matter, organic matter and ash content. J. Ilmiah Peternakan Terpadu. 3(4): 234-238. http://dx.doi. org/10.23960/jipt.v3i4.p\%25p.

- Kung Jr L, Shaver RD, Grant RJ, Schmidt RJ (2018). Silage review: Interpretation of chemical, microbial, and organoleptic components of silages. J. Dairy Sci. 101(5): 4020-4033. https://doi.org/10.3168/jds.2017-13909.

- Leng RA (1990). Factors affecting the utilisation of forages by ruminants under tropical conditions. Nutr. Res. Rev. 3(1):277-303. http://doi.org/10.1079/NRR19900016.

-Luscher A, Mueller-Harvey I, Soussana JF, Rees RM, Peyraud JL (2014). Potential of legume-based grassland-livestock systems in Europe: a review. Grass Forage Sci. 69: 206-228. https://doi.org/10.1111/gfs.12124.

- Machado E, Matumoto Pintro PT, I 'tavo LCV, Agustinho BC, Daniel JLP, Santos NW, Bragatto JM, Ribeiro MG, Zacula LM (2020). Reduction in lignin content and increase in the antioxidant capacity of corn and sugarcane silages treated with an enzymatic complex produced by white rot fungus. PLoS ONE. 15(2): e0229141. https://doi.org/10.1371/ journal.pone.0229141.

- Mccullough ME (1997). Silage and silage fermentation. Feedstuffs. 49: 49-52.

- Morin C, Tremblay GF, Bélanger G, Bertrand A, Castonguay Y, Drapeau R, Michaud R, Berthiaume R, Allard G (2012). Nonstructural carbohydrate concentration during field wilting of PM and AM cut alfalfa. Agron. J. 104: 649-660. https://doi.org/10.2134/agronj2011.0365.

- Moore KJ, Jung H-J G (2001). Lignin and fiber digestion. J. Range Manage. 54: 420-430. https://doi.org/10.2458/azu_ jrm_v54i4_moore.

-Mueller-Harvey I (2006). Unravelling the conundrum of tannins in animal nutrition and health. J. Sci. Food
Agric. 86: 2010- 2037. https://doi.org/10.1002/jsfa.2577

- Muzzazinah (2016). Ethnobotany of Indigofera in Indonesia. Bioedukasi. 9(2): 7-13.

- Nurjannah S, Ayuningsih B, Hernaman I, Susilawati I (2019). The use of Calliandra calothyrsus, Indigofera sp. and its mix in diet to substitute concentrate on productivity of male Garut sheep. JIPT. 7(3): 293 - 298. http://dx.doi.org/10.23960/ jipt.v7i3.p293-298

- Peyraud JL (1993). Comparaison de la digestion du trèfle blance et des graminées prairiales chez la vache laitière. Fourrages 135: 465-473.

- Ratnakomala S, Ridwan R, Kartika G, Widyastuti Y (2006). The effect of Lactobacillus plantarum 1A-2 and 1BL-2 inoculant on the quality of Napier grass silage. Biodiversitas. 7(2) : 131134. http://dx.doi.org/10.13057/biodiv/d070208.

-Riswandi, Priyanto L, Imsya A, Nopiyanti M (2017). In vitro digestibility of fermented Hymenachne acutigluma based rations supplemented with different legumes. J. Vet. 18(2) : 303-311. https://doi.org/10.19087/jveteriner.2017.18.2.303

- Rojas-Downing MM, Nejadhashemi AP, Harrigan T, Woznicki SA (2017). Climate change and livestock: Impacts, adaptation, and mitigation. Clim Risk Manag. 16:145-163. https://doi.org/10.1016/j.crm.2017.02.001

- Sales RMP, Fries DD, Pires AJV, Bonomo P, De Santana SA, Santos IS, Rocha AV, Sobral DMPL (2012). Nitrogen fertilization on the establishment of Arachis pintoi cv. Belmonte. R. Bras. Zootec 41(11): 2303-2308. https://doi. org/10.1590/S1516-35982012001100001

-Salama, HSA, Nawar AI. (2016). Variations of the cell wall components of multi-cut forage legumes, grasses and legume-grass binary mixtures grown in Egypt. Asian J. Crop Sci. 8(3):96-102. http://doi.org/10.3923/ajcs.2016.96.102

-Senjaya OT, Dhalika T, Budiman A, Hernaman I, Mansyur (2010). Effect of storage time and additivies in silage making on neutral detergent fiber and acid detergent fiber of Naiper grass silage. J. Ilmu Ternak. 10(2):85-89. https://doi. org/10.24198/jit.v10i2.425.

-Tahuk PK, Dethan AA (2010). Performance of Bali bull in greenlot fattening by farmers when rainy season in Timor Island. JITAA. 35(4): 257-261. https://doi.org/10.14710/ jitaa.35.4.257-261

-Tarigan A, Abdullah L, Ginting SP, Permana IG (2010). Productivity, nutritional composition and in vitro digestibility of Indigofera sp at different interval and intensity of defoliations. JITV. 15(3): 188-195. https://doi. org/10.14334/jitv.v15i3.657.

- Tarigan A, Ginting SP, Arief II, Astuti DA, Abdullah L (2018). Body weight gain, nutrients degradability and fermentation rumen characteristics of Boerka goat supplemented green concentrate pellets (gcp) based on Indigofera zollingeriana. Pak. J. Biol. Sci. 21 (2): 87-94. https://doi.org/10.3923/ pjbs.2018.87.94.

- Usman Y, Sari EM, Fadilla N (2013). The evaluation of the Aceh cattle bulls weight which compensated between forage and concentrate at superior livestock place in Indrapuri. J. Agripet. 13(2): 41-46. https://doi.org/10.17969/agripet. v13i2.819

-Van Soest PJ, Robertson JB Lewis BA (1991). Methods for dietary fiber, neutral detergent fiber, and nonstarch polysaccharides in relation to animal nutrition. J. Dairy Sci. 74(10):3583-3597. https://doi.org/10.3168/jds.S00220302(91)78551-2 